[Report]

\title{
Decomposition Characteristics of Toluene Vapor Using Titanium Dioxide Photocatalyst and Zeolite Thermally Sprayed on an Aluminum Fiber Filter
}

\author{
Hajime Hori $^{1 *}$, Mitsuo Hinoue ${ }^{1}$, Sumiyo Ishimatsu ${ }^{1}$, Yukiko Fueta ${ }^{1}$, Toru Ishidao ${ }^{1}$, Kaori Takabatake ${ }^{2}$, \\ Natsumi YAKIYAMA ${ }^{2}$ and Kiyoshi Yамамото ${ }^{2}$ \\ ${ }^{1}$ Department of Environmental Management, School of Health Sciences, University of Occupational and Environmen- \\ tal Health, Japan. Yahatanishi-ku, Kitakyushu 807-8555, Japan \\ ${ }^{2}$ Fujico Co. Ltd, Tobata-ku, Kitakyushu 804-0011, Japan
}

\begin{abstract}
Decomposition characteristics of toluene vapor by titanium dioxide photocatalyst and zeolite that are prepared by thermal spraying on an aluminum fiber filter (photocatalyst filter) were investigated. Toluene vapor was injected into a small chamber made of stainless steel, and an air cleaner equipped with the photocatalyst filter was operated. The vapor concentration in the chamber decreased exponentially. The decreasing rate of toluene vapor in the chamber depended on the initial toluene concentration, and the higher the initial vapor concentration was, the lower the decreasing rate was obtained. The decreasing rate was constant during each decomposition experiment, although the concentration decreased with time. To investigate the effect of zeolite on the reduction of the vapor concentration, we compared the decreasing rates of toluene vapor by photocatalyst filters with and without zeolite. The decreasing rate of toluene concentration using the filter without zeolite was larger than that with zeolite. The reason for this would be that photocatalyst decomposed toluene not only in air but also adsorbed in zeolite.
\end{abstract}

Keywords : photocatalyst, titanium dioxide, toluene, zeolite, air cleaner.

(Received September 9, 2016, accepted November 7, 2016)

\section{Introduction}

In the Japanese Industrial Safety and Health Law, installation of an enclosure system, local exhaust ventilation, and push-pull ventilation devices are obliged in designated workplaces using hazardous materials. However, other devices that can prevent diffusion of generated organic vapors into rooms are also approved if their validity and reliability are confirmed.

Recently, photocatalytic technology using oxidation-reduction reaction of titanium dioxide $\left(\mathrm{TiO}_{2}\right)$ has been developed, applying air and water purification, antibacterial and antifungus agents. For air purifying, malodorous gas treating and treatment of volatile organic compounds (VOCs) have been developed [1-5]. Such devices are utilized mainly in indoor environments $[1,2,5,6]$. However, if the devices using photocatalyst can be used in the work environment, they are available for workplaces where ventilation is limited.

The VOC concentrations in indoor environments are relatively lower than those in working environments. Therefore, in order to apply air cleaning devices using a photocatalyst in the working environment, the characteristics of the photocatalyst for the VOC, that is organic solvent vapors, should be known.

In this study, we investigated the basic decomposi-

*Corresponding Author: Hajime HoRI, PhD, Department of Environmental Management, School of Health Sciences, University of Occupational and Environmental Health, Japan. Yahatanishi-ku, Kitakyushu 807-8555, Japan, Tel:+81-93-691-7150, Fax: +81-93-691-2694, E-mail: horih@ med.uoeh-u.ac.jp 
tion characteristics of toluene vapor, which is the most popular organic solvent in workplaces, on titanium dioxide $\left(\mathrm{TiO}_{2}\right)$ photocatalyst and zeolite that are thermally sprayed simultaneously on an aluminum fiber filter (photocatalyst filter), and the application of this photocatalyst filter in the working environments is discussed.

\section{Methods}

Figure 1 shows a schematic diagram of the experimental apparatus. Two sheets of filters with titanium dioxide $\left(\mathrm{TiO}_{2}\right)$ photocatalyst and hydrophobic type zeolite (HiSiv ${ }^{\mathrm{TM}}$ 1000, Union Showa, Tokyo, Japan) $\left(\mathrm{TiO}_{2}:\right.$ zeolite $\left.=9: 1\right)$, which were prepared simultaneously by thermal spraying on aluminum fibers (Fiber diameter : $100 \mu \mathrm{m}$ ) were set in an air cleaner (MaSSC Clean MC-V, Fujico, Kitakyushu, Japan)(2) and placed in a chamber made of stainless steel (volume $150 l$ ) (1). An ultraviolet (UV) lamp and fan of the air cleaner could be operated individually by ON/ OFF switches that were placed outside of the chamber.

Toluene vapor was injected into the chamber with a gas tight syringe to set concentrations of 40, 10, 4 ppm. Only fan was operated for 10 minutes to homogenize air and vapor in the chamber. Then, the UV lamp was switched on from outside of the chamber. Simultaneously, the vapor concentration in the chamber was monitored continuously with a VOC monitor equipped

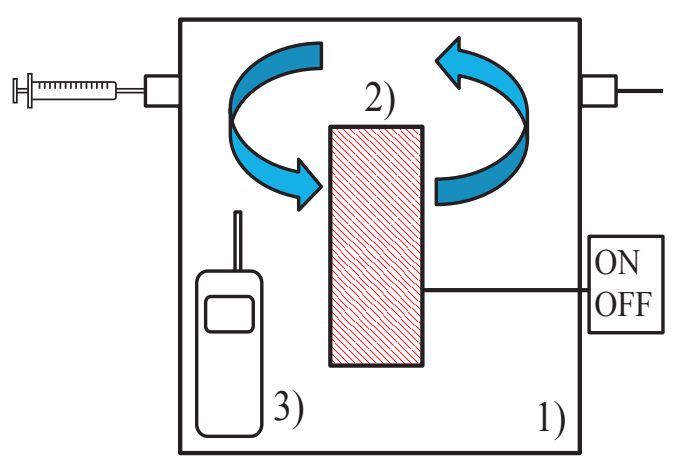

Fig. 1. Schematic diagram of experimental apparatus. 1): stainless steel chamber (volume $150 \mathrm{l}$ ), 2): air cleaner, 3): VOC monitor, VOC: volatile organic compound. with photo ionization detector (PID) sensor (ppb RAE 3000, RAE Systems, USA) (3) and a gas chromatograph equipped with a flame ionization detector (GC) (GC17A, Shimadzu, Kyoto, Japan) (4).

\section{Results and Discussion}

Figure 2 shows the change in vapor concentration of toluene in the chamber measured with GC. The vapor concentrations decreased exponentially. This suggests that the vapor decomposed according to the first order reaction at the surface of photocatalyst; that is, the concentration change is shown as in the following equation:

$$
V \frac{d C}{d t}=-k C
$$

where $V$ is the chamber volume $\left(\mathrm{m}^{3}\right), C$ is the vapor concentration $\left(\mathrm{g} / \mathrm{m}^{3}\right), t$ is the time, $k$ is a constant $\left(\mathrm{m}^{3} / \mathrm{s}\right)$. By integrating Eq.(1) under the initial condition of $C=C_{0}$ at $t=0$ :

$$
C=C_{0} e^{-\frac{k}{V} t}
$$

where $k / V$ means the decomposition rate constant $(1 / \mathrm{s})$.

In the case of $1 \mathrm{ppm}$, we used the VOC monitor to obtain a decomposition curve because the concentration would become so low that accurate quantification might be difficult by the GC. Results are shown in

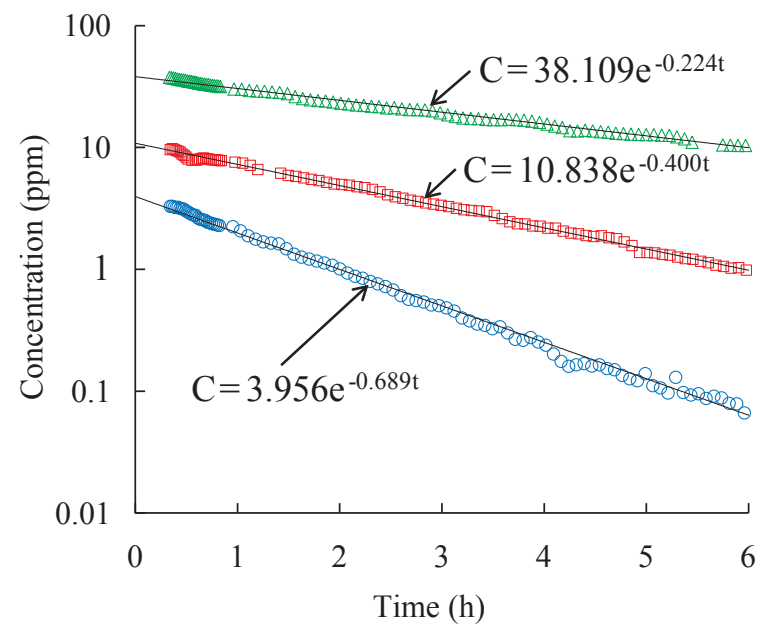

Fig. 2. Change in toluene concentration in the chamber measured with a gas chromatograph. $\triangle: 40 \mathrm{ppm}, \square: 10 \mathrm{ppm}$, $\bigcirc: 4$ ppm, C: vapor concentration of toluene. 
Fig. 3. The decomposition rate was large at first, and then decreased with time, and the curve was expressed as two exponential decay, as follows.

$$
C=1.057 e^{-0.960 t}+0.372 e^{-0.108 t}
$$

The reason for this may be that various kinds of VOCs exist in the chamber because the initial air in the chamber was the same as that in the laboratory. The VOC monitor detects all VOCs in the air nonselectively. The photocatalyst can decompose many VOCs, but the decomposition rate depends on the VOCs. Therefore, when hardly decomposable compounds by the photocatalyst exist in the chamber, the decomposition rate for such compounds is small, and therefore, they remain in the chamber for a long period of time. At first, because toluene concentration was much higher than such VOCs, their effect on the decomposition curve was small, but became large with time and the slope of the decomposition curve changed gentler. If this is the case, the curve in Fig. 3 can be divided in to the decomposition of toluene and that of other VOCs, and we assume that the 1st term on right side in Eq.(3) was the result of the decomposition of toluene and the 2nd term was that of other VOCs.

From Fig. 2, the decomposition rate constant depended on the initial vapor concentration. However, it was constant in each measurement, although the vapor concentration decreased with time. This indicates

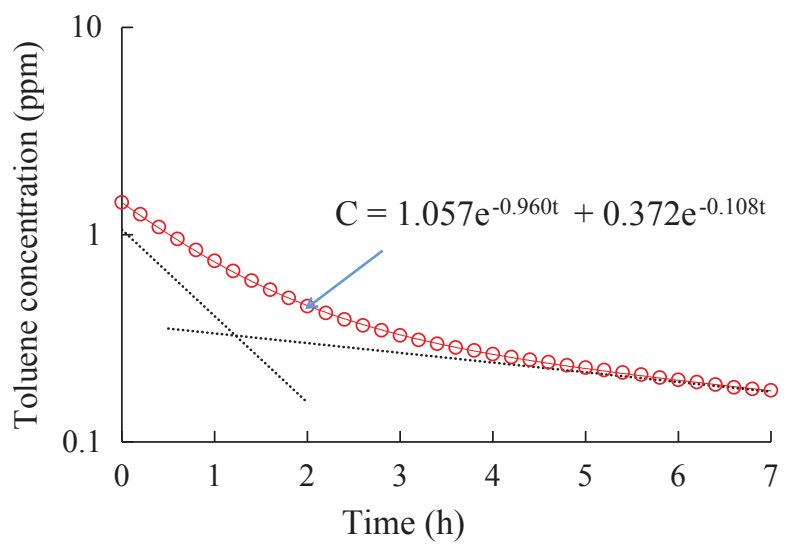

Fig. 3. Change in toluene concentration in the chamber measured with a VOC monitor. VOC: volatile organic compound, $\mathrm{C}$ : vapor concentration of toluene. that the constant decomposition rate did not change even when the vapor concentration decreased due to decomposition by the photocatalyst. But if the decomposition rate is independent of concentration, the slope of the three curves shown in Fig. 2 should be parallel. This discrepancy could be caused by zeolite. The surface of the filter used in this study was covered with not only photocatalyst but also zeolite. Zeolite is an adsorbent and organic vapors are adsorbed on it. Therefore, reduction of the vapor concentration mechanism is not only decomposition of the toluene vapor in air by the photocatalyst but also adsorption by zeolite. Adsorbed vapors are also decomposed by the photocatalyst. If the vapor concentration in the chamber is high, the amount of vapor adsorbed in zeolite is also large because, in general, equilibrated adsorption capacity increases with the increasing vapor concentration. When the vapor concentration was high, the initial amount of adsorbed vapor in zeolite was large, so that the decomposition of toluene adsorbed in zeolite increased. If this is the case, decomposition of the vapor in air by photocatalyst with zeolite should be smaller than that without zeolite because all of the photocatalysts cannot work for decomposition of the vapor in air, and some of the photocatalysts work for decomposition of solvent adsorbed in zeolite. Therefore, the decomposition rate of toluene in air decreased and the slope of the decomposition curve became gentler.

To confirm the above consideration, we used a photocatalysts filter without zeolite and compared the reduction of toluene concentration. In order to avoid the effect of background VOCs, the chamber was closed and an air cleaner with photocatalyst was operated for more than 24 hours to decompose the VOCs in both the air and zeolite in advance. Results are shown in Fig. 4. Compared with Fig. 3, the slope of toluene concentration was larger in both cases because the VOCs, except for injected toluene, in the chamber were so small that the effects of the background VOCs were negligible. The results showed that the slope of vapor concentration by the filter without zeolite was larger than that with zeolite, suggesting that the above consideration is valid.

Takeuchi et al showed $\mathrm{TiO}_{2}$ with $10 \%$ zeolite hybrid photocatalyst indicated higher photocatalytic reactivity 
[7], and Jan et al described that $\mathrm{TiO}_{2}$ /zeolite catalytic adsorbent had a high potential for the removal of multiple air pollutants in the indoor air environment [8]. However, in our experiments, the existence of zeolite in the $\mathrm{TiO}_{2}$ photocatalyst lowered the decomposition rate of toluene vapor in the air. In this study, we used toluene as a test vapor. Because the decomposition characteristics of photocatalyst may be different depending on the vapors, more examination is needed using other solvents.

Photocatalyst is available for improvement of indoor air quality. In this study, the air cleaning characteristics of photocatalyst using titanium dioxide were investigated in order to apply to working environments. However, the decomposition rate of toluene is not large, so that application to workplaces using a large amount of organic solvents may be difficult in the present condition. Improvement of the decomposition rate and the development of decomposition conditions are needed for practical use.

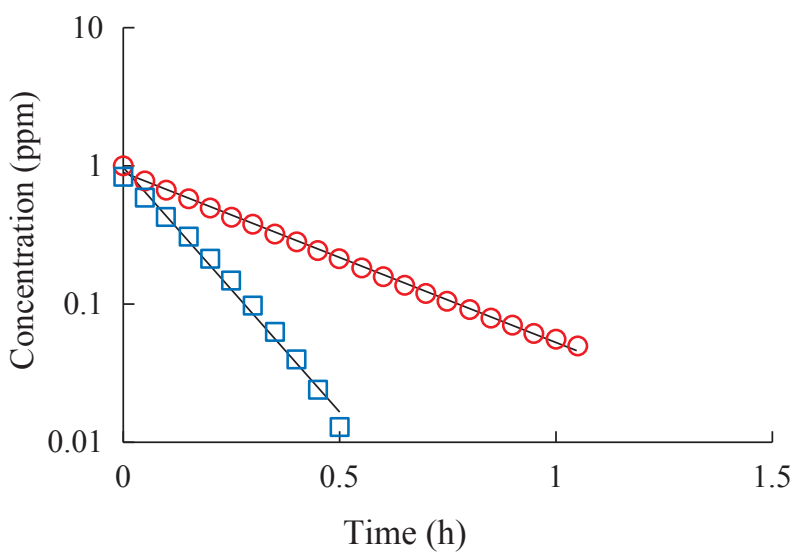

Fig. 4. Comparison of decomposition curves with and without zeolite. $\bigcirc$ : with zeolite, $\square$ : without zeolite.

\section{Conflict of interest}

The authors declare that they have no conflict of interest.

\section{References}

1. Huang Y, Ho SSH, Lu Y, Niu R, Xu L, Cao J \& Lee S (2016): Removal of indoor volatile organic compounds via photocatalytic oxidation: A short review and prospect. Molecules 21: 56

2. Hodgson AT, Destaillats H, Sullivan DP \& Fisk WJ (2007): Performance of ultraviolet photocatalytic oxidation for indoor air cleaning applications. Indoor Air 17: $305-316$

3. Park OH \& Na HY (2008): Photocatalytic degradation of toluene vapour using fixed bed multichannel photoreactors equipped with $\mathrm{TiO}_{2}$-coated fabrics. Environ Technol 29: 1001-1007

4. Young C, Lim TM, Chiang K \& Amal R (2004): Photocatalytic degradation of toluene by platinized titanium dioxide photocatalysts. Water Sci Technol 50(4): 251256

5. Chapuis Y, Klvana D, Guy C \& Kirchnerova J (2002): Photocatalytic oxidation of volatile organic compounds using fluorescent visible light. J Air Waste Manag Assoc $52: 845-854$

6. Higuchi T, Haraga H, Yoshinaga H, Umeda Y \& Yamasaki $\mathrm{T}$ (2009): Development of living environmental cleaning products by photocatalytic spray coatings. Tsukuru: FUJICO Technical Report 17: 49-55 (in Japanese)

7. Takeuchi M, Hidaka M \& Anpo M (2012): Efficient removal of toluene and benzene in gas phase by the $\mathrm{TiO}_{2} /$ Y-zeolite hybrid photocatalyst. J Hazard Mater 237-238: 133-139

8. Jan YH, Lin LY, Karthik M \& Bai H (2009): Titanium dioxide/zeolite catalytic adsorbent for the removal of NO and acetone vapors. J Air Waste Manag Assoc 59: 1186-1193 
アルミ繊維に酸化チタン光触媒とゼオライトを溶射したフィルターのトルエン分解特性

保利 - ${ }^{1}$, 樋上 光雄 ${ }^{1}$, 石松 維世 ${ }^{1}$, 笛田 由紀子 ${ }^{1}$, 石田尾 徹 ${ }^{1}$, 高畠 伽央里 ${ }^{2}$, 燒山 なつみ ${ }^{2}$, 山本 清司 ${ }^{2}$

1 産業医科大学 産業保健学部 環境マネジメント学科

²株式会社フジコー 技術開発センター

要旨：アルミ繊維に酸化チタン光触媒とゼオライトを溶射したフィルター(光触媒フィルター)を用いて, 代 表的有機溶剤であるトルエンの分解特性を検討した，ステンレス製のチャンバー内にトルエン蒸気を注入し, 光触 媒フィルターをセットした空気清浄機を稼働させ, トルエン濃度の経時変化を観察した。 チャンバー内のトルエン 濃度は指数関数的に減少したが, 減少速度は低濃度に比較して高濃度の方が小さくなった。この原因として, 光触媒 溶射時に添加したゼオライトの影響が考えられたため, ゼオライトを除いた光触媒単体溶射フィルターを用いて同 様に分解特性を調べた結果, 光触媒単体溶射フィルターの方が光触媒とゼオライトを溶射したフィルターよりも分 解速度が大きいことがわかった。この原因として, 光触媒が環境中のトルエンに加えて, ゼオライトに吸着したトル エンの分解にも関与したため, その分環境中のトルエンの分解速度が小さくなったことが考えられた。

キーワード : 光触媒, 酸化チタン, トルエン, ゼオライト, 空気清浄機.

J UOEH(産業医大誌) 38(4)：305 - 309（2016） 